\title{
Conservation priorities in Burma
}

\author{
John Blower
}

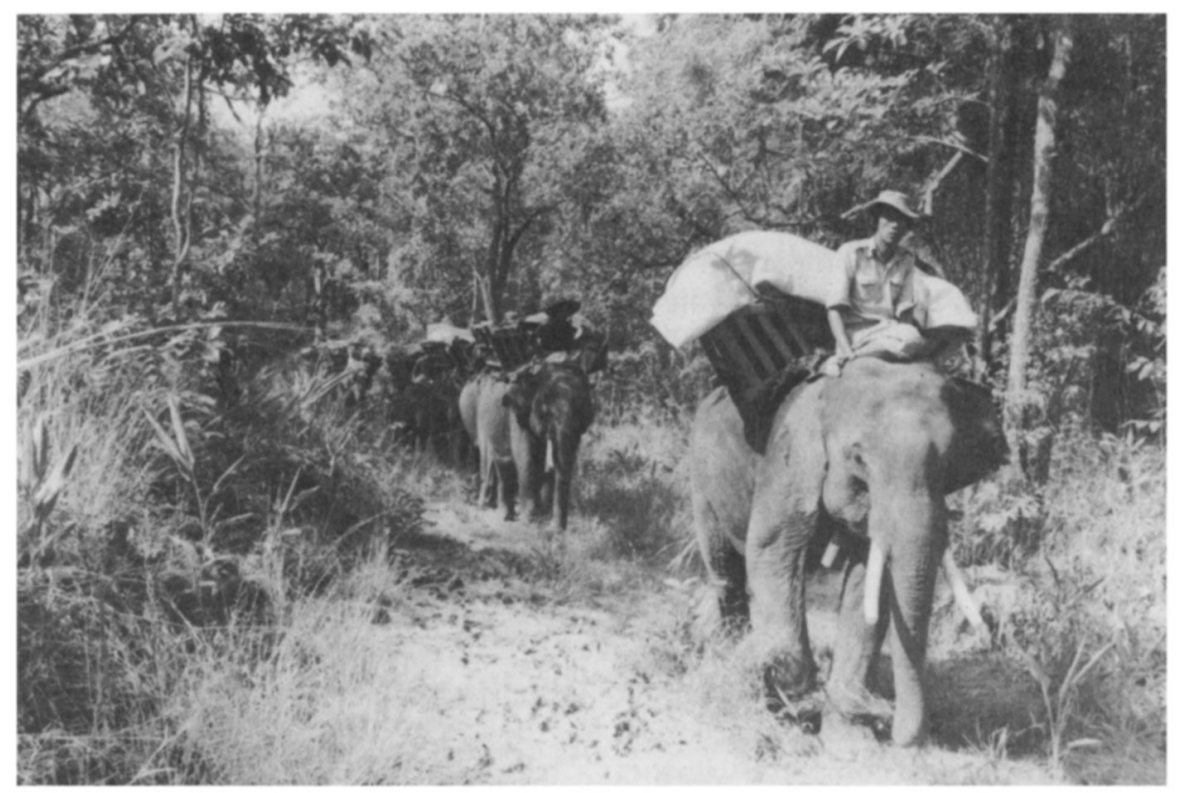

Survey party's baggage elephants in Indaing forest, proposed Alaungdaw Kathapa National Park (John Blower).

In 1981 the Government of Burma, conscious that it should be doing more to conserve its natural resources, invited the Food and Agriculture Organisation and the Development Programme of the United Nations to assist in a project to identify areas suitable for national parks and reserves. The Minister of Agriculture and Forests has already decided to establish one of the proposed parks, Alaungdaw Kathapa, and it is hoped that the rest will follow. The author was in charge of the project for its three-year duration.

Burma, 261,720 square miles $(677,855 \mathrm{sq} \mathrm{km})$ in area, is the largest country in mainland South-
East Asia; it extends from $10^{\circ} \mathrm{N}$ at its southern tip to $28^{\circ} \mathrm{N}$ on the northern border with 'China (Tibet), a distance of about 1300 miles (2092 $\mathrm{km})$. The dominant topographical features are the relatively densely populated central basin of the Irrawaddy-Chindwin river system, and the peripheral mountain ranges in the form of an inverted horseshoe-shaped barrier, which separates Burma from Bangladesh and India to the west, China to the north and east, and Laos and Thailand to the east and south.

There are four major forest types. The mixed deciduous forests, important economically as the source of teak and other commercial hardwoods, 
cover much of central Burma outside the Dry Zone. Evergreen forests occur in the north and south, reaching their maximum development as tropical wet evergreen forest in Tenasserim. Freshwater and tidal swamp forest, including mangrove forests, occur along the coasts of Arakan and Tenasserim and in the Irrawaddy delta. Temperate and alpine forests are found in the far north.

'Forest', according to official government publications, still covers 57 per cent of Burma's total land area. But while this may have been true 20 years ago, it is no longer so. Analysis of 1975 satellite imagery under the FAO/UNEP survey of forest resources of tropical Asia (FAO, 1981) showed about 47 per cent forest cover at that time, including shrub formations and extensive areas of secondary bamboo. Comparison with previous figures indicated a deforestation rate of about 250,000 ha per year.

Study of more recent satellite and air photographs by the FAO National Forest Inventory Project has shown that in the five years between 1975 and $198036,880 \mathrm{sq} \mathrm{km}$ (14,240 sq miles) of forest were lost, reducing the total, including degraded forest, to 42 per cent, reflecting a deforestation rate of some 737,850 ha $(2850 \mathrm{sq}$ miles) per year, or approximately three times the 1975 rate. Assuming that deforestation has continued at a similar rate since 1980 , total forest cover is now about 37 per cent compared with the 57 per cent still complacently quoted in official publications.

Existing forest reserves, which theoretically cover 13 per cent of the country, are managed primarily for timber production. Timber, principally teak, is one of the country's main foreign exchange earners, and its exploitation is a monopoly of the State Timber Corporation. The Forest Department, one of the oldest in Asia, is technically still responsible for managing the forests, but is hampered by serious shortages of staff and funds, and by the fact that it has little control over the politically more powerful Timber Corporation.

Most of the forest reserves were established towards the end of the last century when pressure on the natural environment was negligible. Their main purpose was to safeguard the most valuable stands of commercial timber, with little regard to 80 the need for protecting forest per se. Today the needs are both very different and much more urgent. There is, for example, not a single protection reserve in the whole upper catchment area of the Irrawaddy to the north of Myitkyina, where maintenance of forest cover is obviously of critical importance.

Among the highest forest conservation priorities, apart from watershed protection and continued management of the teak forests on a sustainable basis, is the protection of Burma's evergreen forests, especially the dipterocarp-rich forest of south Tenasserim, and the coastal mangroves. Mangroves in the Irrawaddy delta are increasingly threatened by over-exploitation for charcoal and fuelwood, and by clear-felling to extend the area under rice cultivation. If this is allowed to continue, the economically important coastal prawn and shrimp fisheries will inevitably be affected. Other priorities include the protection of areas of undisturbed natural teak forest to ensure future supplies of selected seed for commercial plantations, and of individual tree species that appear in danger of extinction in the wild (Amherstia nobilis an ornamental tree endemic to Burma, and Taiwania cryptomeriodes the Chinese coffinwood tree, for example).

\section{Wildlife}

As for wildlife, most of Burma lies within the Indochinese zoogeographic Sub-Region of the Oriental Region, though the Arakan and Chin Hills are in the Indian Sub-Region, and the high mountains of the far north, with their typically Himalayan fauna, are within the Palearctic Region. Elephant, gaur, banteng, sambar, barking deer, tiger, leopard, Himalayan bear and other characteristic Indo-Malayan mammal species occur in most of the less disturbed forests, but populations have been greatly reduced and are continuing to decline through habitat loss and over-hunting.

Other species with more local distribution include: thamin, which are confined to the drier areas of central Burma; hog deer; musk deer, found in the alpine areas of the north (seriously endangered through over-hunting); and two species of mouse deer in Tenasserim. There are also four species of goat antelope: takin, found in

Oryx Vol 19 No 2 
Scientific names of animals in text

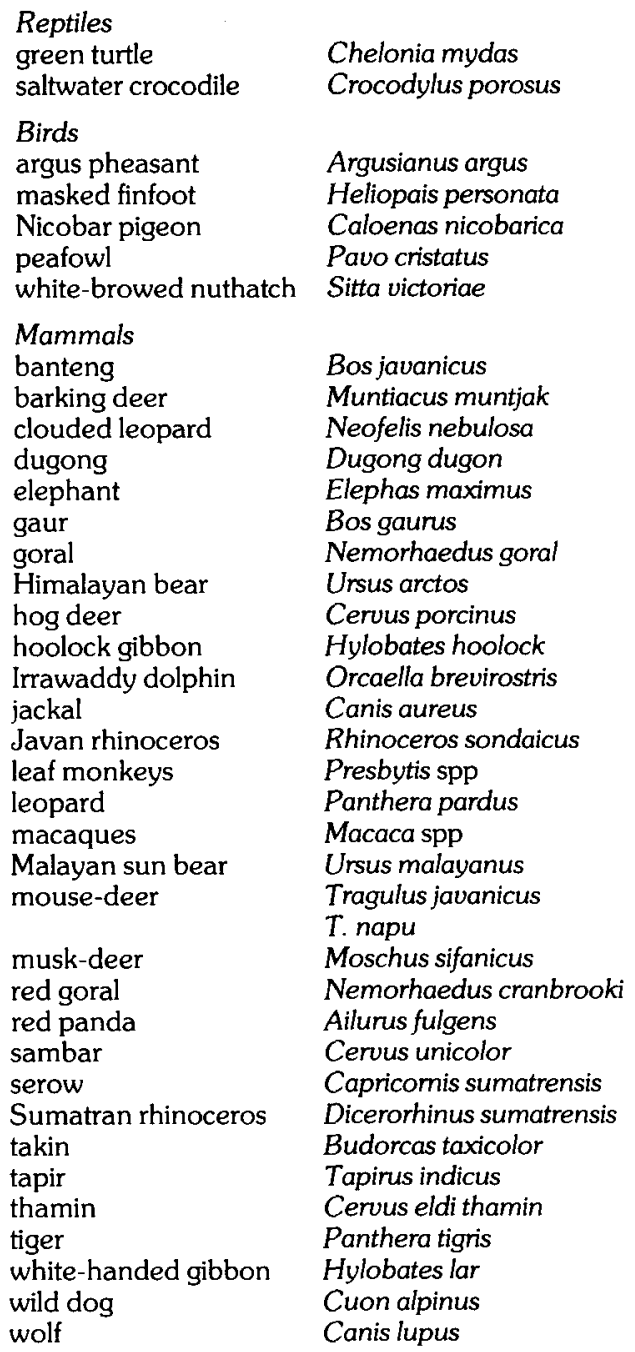

Nomenclature follows:

Howard, R. and Moore, A. 1980. A Complete Checklist of the Birds of the World. Oxford University Press.

Nowak, R.M. and Paradiso, J.L. 1983. Walker's Mammals of the World. The John Hopkins University Press, Baltimore.

the north of Kachin State; serow; and two species of goral, one of them the rare red goral, endemic to northern Kachin State and adjoining areas of Tibet and India.

Tapir occur only in sourthern Tenasserim, where they still appear to be locally plentiful. Of the two species of rhinoceros formerly occurring in Burma, the Javan is already extinct and the Sumatran probably so. The large carnivores include tiger, leopard, clouded leopard, Himalayan and Malayan bear, wild dog, jackal, red panda and probably wolf, the last two species being confined to northern Kachin State. Among primates there are several macaques and leaf monkeys, and two gibbons; the hoolock, fairly widely distributed in Upper Burma, and the white-handed gibbon of Malaysia, whose range extends northwards into Tenasserim.

Marine mammals and reptiles occurring in coastal waters and estuaries include dugong (now very rare), the saltwater crocodile and possibly five species of marine turtle, of which the most common is the green turtle. The Irrawaddy dolphin formerly occurred 900 miles (1448 km) upstream from the Irrawaddy delta, but there is no information on its present range or status.

About 1000 bird species have been recorded from Burma (Smythies, 1953). This relatively high species diversity is due to the fact that the country extends into two zoogeographic zones, each with different bird faunas. Many Malaysian species are found in Tenasserim forests; in the central and northern parts of Burma, the bird fauna has Indian and Chinese affinities; a large number of Himalayan species, including pheasants, occur in the montane forests of the north and north-west.

No national parks or nature reserves have yet been established in Burma. The 14 wildlife sanctuaries are mostly small and total only 0.7 per cent of the land area. This compares unfavourably with the average total protected area of neighbouring countries in South and South-East Asia (about 5 per cent), and would be inadequate even if the sanctuaries were protected effectively, which they are not. Under the existing outdated legislation (Forest Act, 1902, and the Wildlife Protection Act, 1936), the fauna in the sanctuaries is protected, but the habitat is not, with the result that some of the most valuable areas such as Shwe-u-daung (one of the last known habitats of the Sumatran rhinoceros in Burma), have been logged, while others have suffered serious encroachment. Damage to some has been so severe that they are now of little conservation value. 


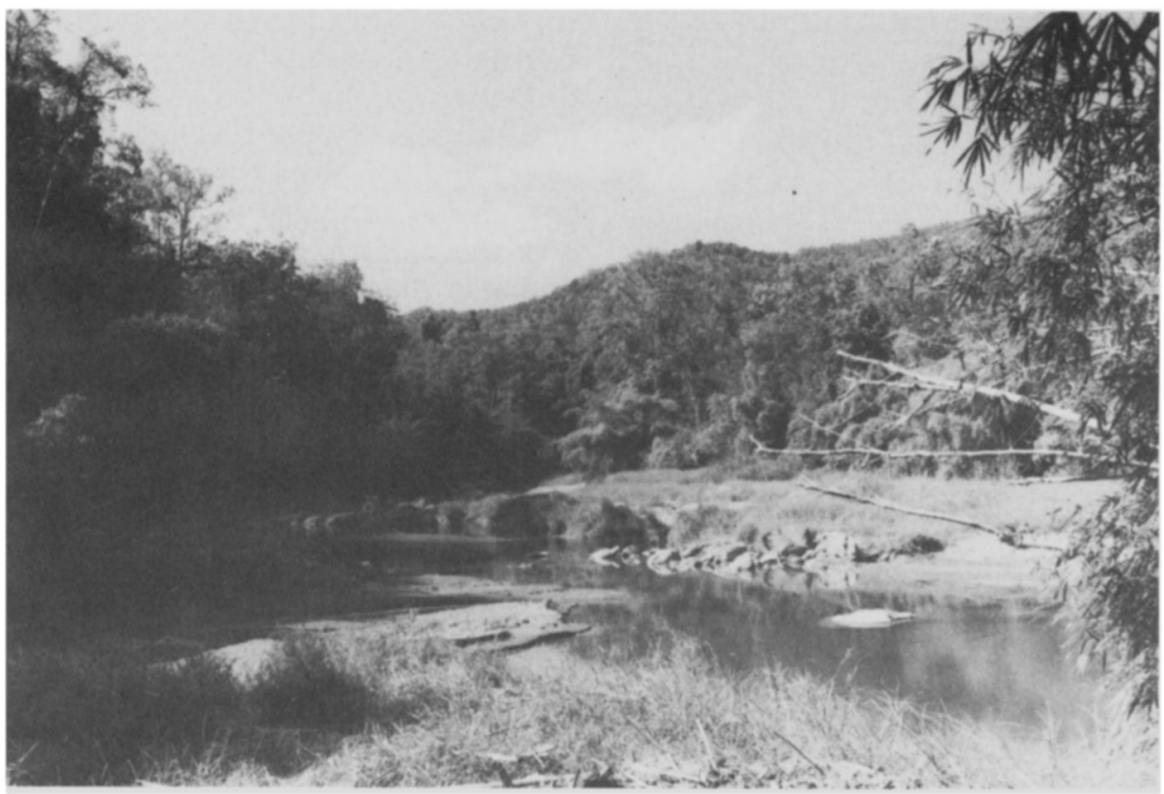

Patolon River in the proposed Alaungdaw Kathapa National Park (John Blower).

Nature conservation remains the legal responsibility of the Forest Department, but it has insufficient staff to enforce the law effectively. The development of national parks, however, has somewhat incongruously been placed under the Working People's Settlement Board, an agency originally created for resettlement of ex-servicemen and now concerned primarily with management of the State Agricultural Farms. This has not so far proved satisfactory. The Settlement Board is under the control of military personnel who have neither the requisite professional qualifications nor the necessary motivation.

\section{Elephant smuggling}

The issue of hunting licences has been officially suspended since 1958. Nevertheless, hunting continues and there are numerous firearms in the hands of the army, the People's Militia and the various insurgents; poaching for meat is widespread. There is also extensive hunting of elephant for ivory, and both legal and illegal capture of elephant. An average of about 120 animals are taken annually by the State Timber Corporation and their contractors to maintain the stock of some 5400 timber-working elephants. Others are illegally captured and smuggled to 82
Thailand where they fetch high prices in much sought-after foreign currency. Mortality in the course of both capture and training is high, and there are no reliable data on the size of the wild elephant population thus being diminished. Estimates have been made between 3000 and 6000 ; the lower figure is likely to be the most accurate: both the number and the range of wild elephants in Burma is decreasing rapidly.

The only species fully protected under present legislation are: rhinoceros (probably already extinct), tapir, thamin, argus pheasant, masked finfoot and peafowl. Elephant, banteng, gaur, goral and serow can theoretically only be hunted under licence, but the fact that no licences have been issued since 1958 has not meant that hunting has stopped-or lessened. There is no legal protection whatsoever for tiger, clouded leopard, dugong, musk deer, saltwater crocodile or marine turtles, all of which must be considered vulnerable, if not endangered.

\section{Encouraging moves}

Burma is far behind most other countries of South and South-East Asia in the field of nature conservation, but the start made recently with an Oryx Vol 19 No 2 
FAO/UNDP assisted project is encouraging. The three-year project, which ended in 1984, was concerned primarily with field surveys and identification of areas suitable as national parks or nature reserves, including the re-evaluation of existing wildlife sanctuaries. Unfortunately, some of the most promising (Tramanthi, Pidaung, Shwe-u-daung Sancturaries, all of Kachin State and much of eastern Burma) are inaccessible for security reasons, and the surveys were thus very restricted. It was nevertheless possible to identify several potentially valuable conservation areas in which the establishment of national parks or other forms of protection have been proposed:

\section{National Parks}

Alaungdaw Kathapa ( 620 sq miles, 1606 sq km): a mountainous tract, approximately 100 miles (161 km) west of Mandalay, forming the watershed between the Chindwin and Myittha rivers, mostly covered with mixed deciduous forest, but including some evergreen forest and pine on the higher ridges, some of which rise to over $4000 \mathrm{ft}$ $(1219 \mathrm{~m})$. The area has been classed as reserved forest since 1893. It has been selectively logged for teak in the past but on the whole little disturbed. Larger mammals: elephant, gaur, banteng, sambar, Himalayan bear, leopard and a relatively large population of tiger. The proposed park comprises the upper drainage basins of two perennial rivers, the Patolon and the Taungdwin, both western tributaries of the Chindwin.

Lampi: the proposed Lampi Marine Natural Park would include a number of islands of the Mergui Archipelago off the coast of southern Tenasserim. With a total area of some 1500 sq miles (3885 sq $\mathrm{km}$ ), if the intervening sea areas are included, the park would be centred on Lampi, the largest of the islands (c. $65 \mathrm{sq}$ miles, $168 \mathrm{sq} \mathrm{km}$ ) where the Park Headquarters would probably be located a beautiful island covered with almost undisturbed evergreen forest, with mangroves and extensive coral reefs around the neighbouring islands. The rare Nicobar pigeon has been reported. All islands within the proposed park are uninhabited except by the migratory Salon people, so-called sea gypsies, for whom they are a monsoon refuge/anchorage. The park would also serve to protect them from the influences that threaten their way of life.
Kyaukpandaung (c. 50 sq miles, $130 \mathrm{sq} \mathrm{km}$ ): an isolated plateau in the southern Chin Hills, guarded by precipitous limestone cliffs on three sides, which provides ideal goral and serow habitat. It is covered with relatively undisturbed evergreen forest - the last such tract in this area now largely covered with the creeping rhizomed bamboo Melocanna bambusoides. Wildlife: goral, serow, hoolock gibbon, gaur, sambar, leopard and occasional elephant

Natma Taung (Mt Victoria): also in the southern Chin Hills about 70 miles $(113 \mathrm{~km})$ east of Kyaukpandaung; at $10,018 \mathrm{ft}(3053 \mathrm{~m})$ it is the highest mountain in central and southern Burma with special value as an ecological island. Botanically interesting temperate flora and an avifauna that includes one endemic species, the white-browed nuthatch, and five other bird species unrecorded elsewhere in Burma. Larger mammals: hoolock gibbon, tiger, leopard, serow, goral, Himalayan bear and sambar. A national park of $140 \mathrm{sq}$ miles (362 sq $\mathrm{km}$ ) is proposed, subject to further survey.

\section{Nature Reserves}

Pakchan (c. $250 \mathrm{sq}$ miles, $648 \mathrm{sq} \mathrm{km}$ ): on the mainland of southern Tenasserim directly opposite the proposed Lampi Marine Park, it could be managed as an adjunct to the park. Particularly important is the fine tropical moist evergreen forest with several species of dipterocarp. Largely Malayan fauna here: both species of mouse deer, many tapir, gaur, banteng, sambar, elephant, tiger and Malayan sun-bear. Extensive tidal swamps and shallow rivers provide excellent mangrove habitat, so far little disturbed, unlike the dipterocarps which are heavily tapped for resin. The reserve would also protect the watershed between the coast and the Pakchan River, here forming the border between Burma and Thailand.

A number of smaller areas have also been proposed as either nature reserves or wildlife sanctuaries, including several coastal or inland wetlands for waterfowl conservation, and marine islands for the protection of turtle nesting sites. Of the already existing wildlife sanctuaries, those with the highest conservation priority are:

Tamanthi ( $830 \mathrm{sq}$ miles, $2150 \mathrm{sq} \mathrm{km}$ ): on the east 


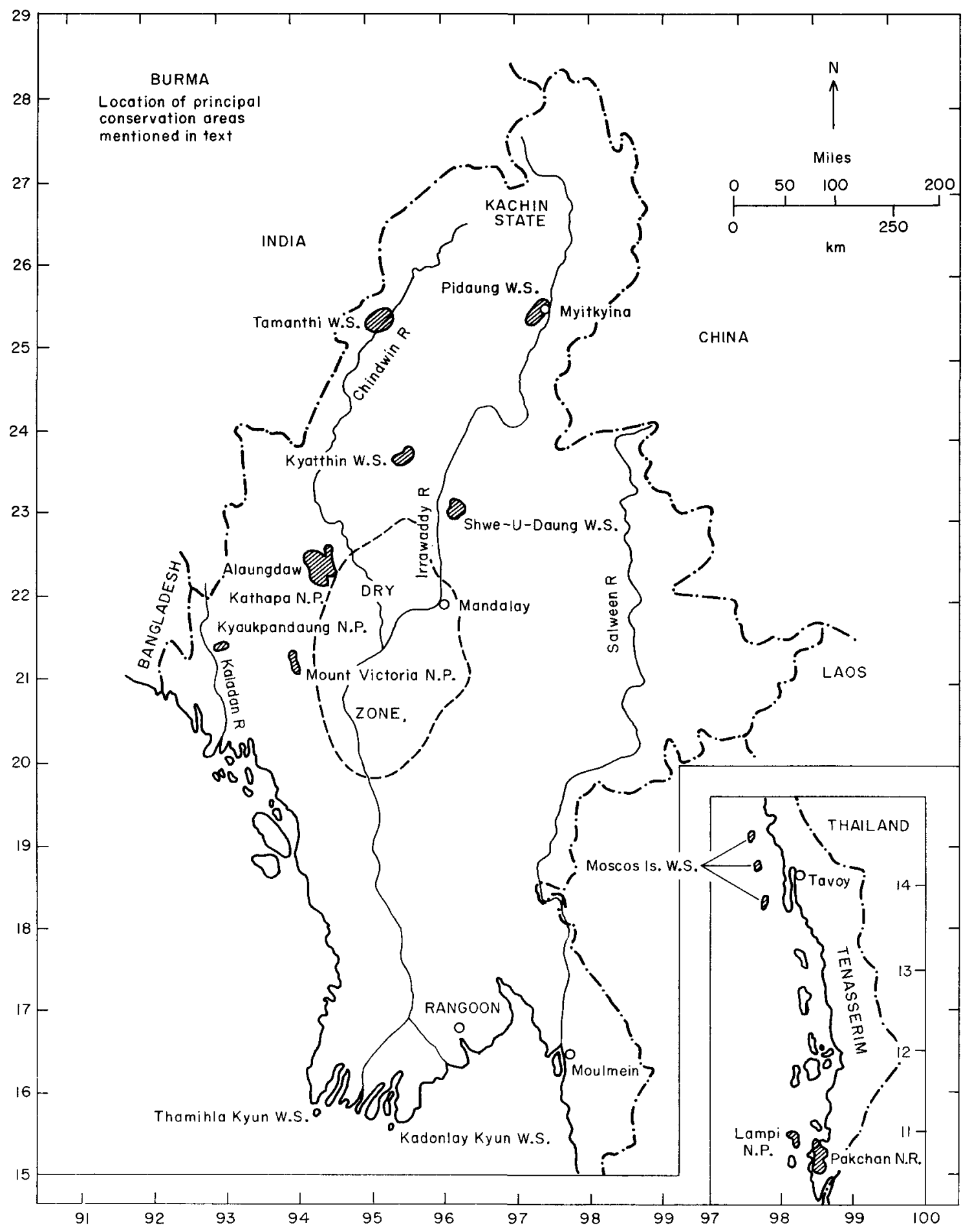


bank of the upper Chindwin and consisting mainly of tropical evergreen forest with some mixed deciduous and hill forest types. It is here that the Sumatran rhinoceros might still occur; it is also valuable elephant habitat-the remaining wild elephant populations are to be found mainly in northern Burma. Tamanthi has not been surveyed yet for security reasons.

Kyatthin (104 sq miles, 269 sq km): about 100 miles (161 km) NNW of Mandalay; mainly dry deciduous or indaing forest and much disturbed by encroachment, but still containing the largest known population of thamin, the subspecies of Eld's deer endemic to Burma - of which the range and numbers are now so reduced that it must be considered endangered.

Thamihla Kyun or Diamond Island (0.4 sq miles, $1 \mathrm{sq} \mathrm{km}$ ) off the mouth of the Bassein River at the west side of the Irrawaddy delta; the most important known nesting site of marine turtles on the Burmese coast. The eggs have been collected under government licence for over 80 years; the $1900-1910$ records shown an annual average of 1.5-2 million eggs. The island was declared a wildlife sanctuary in 1970, but the People's Pearl and Fisheries Corporation (PPFC) continue to collect nearly all the eggs. The average harvest is now only $150,000-200,000$. There is also reported to be heavy mortality among adult breeding turtles caught accidentally by PPFC trawlers operating nearby.

Of the areas so far proposed for protection, only one, Alaungdaw Kathapa, has so far been officially approved as a national park. If the other areas described could be protected in some form, this would be a considerable advance, but would neither provide adequate coverage of major ecosystems nor ensure the survival of even such an important species as elephant.

The two regions of greatest ecological diversity that should have high priority in planning additional protected areas are the extreme north (Kachin State) and southern Tenasserim. Both are tropical moist forest, though species composition is different, and the northernmost part of Kachin State also has temperate and alpine vegetation; the fauna is Himalayan-takin, musk deer, red panda, probably wolf-although at lower altitudes one finds typical rain-forest

Conservation priorities in Burma species. The establishment of protected areas in northernmost Burma would also serve to protect the upper catchments of the Irrawaddy, a matter of vital importance, which should have high priority in Burmese land-use planning. In southern Tenasserim, on the other hand, is found the most highly developed moist evergreen forest and associated fauna. The forest here is under increasing pressure from local people (resin tapping, mangrove charcoal, timber exploitation) and the highly organised Thai timber thieves. The mangroves and offshore coral also protect the fisheries on which the southern Burmese depend.

As for individual species, the most endangered are undoubtedly the elephant and the marine turtles, since both are being exploited commercially. Status surveys of these are urgently needed. They need sanctuaries worthy of the name, and a high priority should be given to the establishment of elephant ranges in which land use is strictly controlled. The management of already captive elephants and their initial training should be improved; there is much 'wastage', which results from mistreatment, and the reproductive rate of Burmese captive herds compares unfavourably with Assamese and Ceylonese records.

A greatly strengthened Forest Department with enough trained staff and funds to manage an increased number of protected areas efficiently is also an urgent requirement. At present Forest Officers are too thinly spread for even effective forest management.

Finally, there is legislation and education. New legislation in line with present-day management techniques and requirements must be in force before any national park or nature reserve can be efficiently managed in Burma, and the Burmese people at all levels should become more aware, through conservation education, of environmental problems.

\section{References}

FAO 1981. Forest Resources of Tropical Asia. Food and Agriculture Organisation of the United Nations, Rome.

Smythies, B.E. 1953. The Birds of Burma. Oliver and Boyd, Edinburgh.

John Blower, Beau Pré, St Martins, Guernsey, Channel Islands. 